\title{
Prevalence of HCV genotypes in district Mardan
}

\author{
Suliman Qadir Afridi', Muhammad Nouman Zahid', Muhammad Zubair Shabbir ${ }^{2}$, Zeenat Hussain ${ }^{3}$, \\ Nadia Mukhtar', Muhammad Yasin Tipu', Fareeha Akhtar ${ }^{2}$ and Tahir Yaqub ${ }^{1 *}$
}

\begin{abstract}
Background: Approximately 170 million people are infected with Hepatitis C virus (HCV) worldwide. The prevalence of chronic HCV infections in Pakistan is about $5 \%$, with most individuals being infected with HCV genotype 3a. Data on HCV genotypes distribution across various districts of the country are scarce. One example is district Mardan from where such data is available only from 17 individuals. Accordingly, the present study aimed at determining HCV genotypes distribution among 177 HCV RNA positive individuals from district Mardan.

Findings: Serum samples $(n=215)$ from patients suspected of hepatitis $C$ were collected and processed for Nested PCR based detection and subsequent genotyping. Gender-wise and age-wise differences in HCV prevalence and HCV genotypes distribution were determined by $x 2$ test. Out of the total 215 serum samples, 177 were found to be positive for HCV RNA. The genotype 3a was the most predominant genotype among HCV RNA positive samples with a prevalence of $90.3 \%$, followed by genotype 1a (5.6\%), mixed genotypes (2.8\%), genotype $3 \mathrm{~b}(0.6 \%)$ and genotype $4(0.6 \%)$. The HCV prevalence was higher in young individuals than old people and was indicative of reduced survival rate beyond 40 years.
\end{abstract}

Conclusion: HCV genotype $3 a$ is the most predominant genotype in district Mardan. The state of the art preventive and therapeutic strategies should be implemented to control the spread of HCV infections. Further temporal studies involving different geographical areas of Pakistan, are required to improve the control measures for HCV infection.

Keywords: Hepatitis, Hepatitis C virus, HCV genotypes, Prevalence, Pakistan

\section{Findings}

Hepatitis $\mathrm{C}$ is an infectious disease caused by Hepatitis $\mathrm{C}$ virus $(\mathrm{HCV})$. $\mathrm{HCV}$ has a major impact on public health with over 170 million infected individuals. It has been considered to cause $25 \%$ of hepatocellular carcinoma (HCC) and $27 \%$ of cirrhosis cases all over the world [1]. Death rate due to $\mathrm{HCV}$ infection is very high and approximately 350,000 people die every year after being infected with $\mathrm{HCV}$. It is thought that $\mathrm{HCV}$ is 10 times more infectious than human immunodeficiency virus (HIV) [2]. Toxicity, resistance and cost of the treatment limit current therapy of $\mathrm{HCV}$. To date, no vaccine or immunotherapy is available.

$\mathrm{HCV}$ is an enveloped positive-strand RNA virus. It belongs to the genus hepacivirus that is part of Flaviviridae family. HCV virion size is about $55-65 \mathrm{~nm}$ in diameter [3]. HCV genome (approximately $9.6 \mathrm{~kb}$ ) encodes a

\footnotetext{
* Correspondence: tahiryaqub@uvas.edu.pk

'Quality Operations Laboratory, UVAS, Lahore 54000, Pakistan

Full list of author information is available at the end of the article
}

polyprotein of about 3,010 amino acids, which is flanked at the 5'- and 3'- ends by small highly structured untranslated regions (UTR). This polyprotein precursor is cleaved by viral and cellular proteases, giving rise to 10 mature structural and nonstructural proteins. Core, E1 and E2 are structural proteins while a small hydrophobic peptide 7 separates the structural proteins from nonstructural proteins (NS). The nonstructural proteins include NS2, NS3, NS4A, NS4B, NS5A, and NS5B [4]. $\mathrm{HCV}$ envelope glycoprotein E1 and E2 are important for viral entry. HCV core protein interacts with lipid droplets [5] while $\mathrm{p} 7$ has been shown to participate in assembly and release of HCV particles [6]. NS2 has been shown to interact with envelope glycoproteins, p7 and NS3 and recruits viral proteins to lipid droplets [7]. NS3 protein plays a role in the recruitment of NS5A to lipid droplets and in the assembly of viral particles [8]. The formation of membranous web is the important function of NS4B [9]. The interaction of NS5A and apolipoprotein (ApoE) is required for the assembly and export of
C Biomed Central

(c) 2013 Afridi et al.; licensee BioMed Central Ltd. This is an Open Access article distributed under the terms of the Creative Commons Attribution License (http://creativecommons.org/licenses/by/2.0), which permits unrestricted use, distribution, and reproduction in any medium, provided the original work is properly cited. 


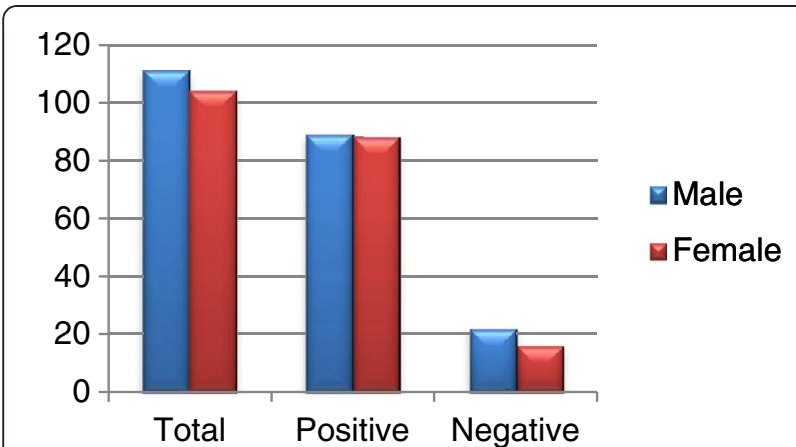

Figure 1 Prevalence of HCV RNA positive samples.

infectious virions [10]. NS5B is a RNA-dependent RNA polymerase (Dry) that is a critical enzyme for HCV RNA replication.

$\mathrm{HCV}$ shows high genetic variability and therefore, it is divided into six major genotypes and multiple subtypes. $\mathrm{HCV}$ has heterogeneous geographical distribution. HCV genotypes 4, 5 and 6 are restricted to more precise geographic regions (i.e., South Africa and Southeast Asia, Egypt, and Africa, correspondingly), whereas genotypes 1, 2, and 3 have a global distribution. In addition, being limited to different geographical areas these six genotypes have their own distinctive pattern of disease development and response to therapy.

In Pakistan, prevalence of HCV is $4.7 \%$ [11]. One of the major reasons for chronic $\mathrm{HCV}$ infection is lack of awareness of the disease and regular blood analysis, so most of the individuals remain ignorant about their status of HCV infection. A little has been reported about $\mathrm{HCV}$ and its genotypes prevalence in Pakistan. Therefore, this work has been conducted to determine baseline data on the prevalence of HCV genotypes in a district in North of Pakistan, the Mardan. The baseline information will serve in better understanding of infection, awareness in the public and subsequent control strategies.

The study was approved by Ethical Committee Bacteriologist to Government of Punjab, Health Department (No. 677/Bact.). From hundreds of blood samples referred from district Mardan to The Medical Laboratory, Lahore for the detection and genotyping of $\mathrm{HCV}$

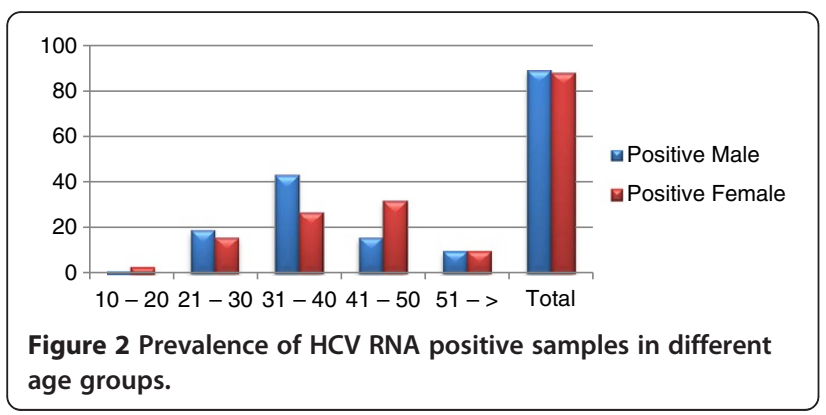

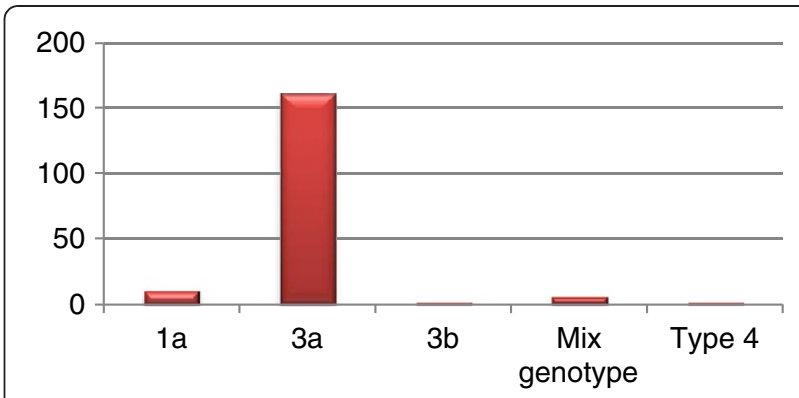

Figure 3 Prevalence of different HCV genotypes in Mardan.

RNA, a total of 215 blood samples were randomly selected to detect and genotype HCV RNA. The age of clinically suspected hepatitis $\mathrm{C}$ patients was between $10-50$ years. Of these 111 were males and 104 were females. Serum from each blood sample was separated at $3000 \mathrm{~g}$ for $5 \mathrm{~min}$, labeled and stored at $-20^{\circ} \mathrm{C}$ until used within a week. RNA was extracted using Qiagen kit (Invitrogen, Corp., California; USA) as per manufacturer's instructions. Complimentary DNA (cDNA) was synthesized using Invitrogen kit as per manufacturer's instructions. Briefly, $10 \mu \mathrm{L}$ of extracted RNA was incubated at $37^{\circ} \mathrm{C}$ for $60 \mathrm{~min}$ along with gene-specific reverse primer and 200U of Moloney Murine Leukemia Virus (M-MuLV) reverse transcriptase. The cDNA was amplified through Nested PCR.

Different HCV genotypes were detected by using allelespecific primers reported by Ohno et al. [12]. Temperature profile of PCR machine was adjusted at $94^{\circ} \mathrm{C}$ for $5 \mathrm{~min}$ for initial denaturation, followed by 35 cycles, each of $45 \mathrm{~s}$ denaturation at $94^{\circ} \mathrm{C}, 45 \mathrm{~s}$ annealing at $62^{\circ} \mathrm{C}$ and $45 \mathrm{~s}$ extension at $72^{\circ} \mathrm{C}$, with final extension at $72^{\circ} \mathrm{C}$ for $5 \mathrm{~min}$. The final PCR product obtained either after qualitative or genotype-specific PCR was subjected to electrophoresis in $2 \%$ agarose gel containing ethidium bromide along with 100-bp DNA ladder (Invitrogen, Corp., California; USA). The banding pattern, to determine genotype specific bands, was photographed in Gel Doc System. The prevalence and distribution of each genotype among different age groups and sex was analyzed by Chi-square statistics

Table 1 Prevalence of HCV genotypes in different age groups

\begin{tabular}{|c|c|c|c|c|c|c|c|}
\hline \multirow[t]{2}{*}{ Age group } & \multicolumn{7}{|l|}{ Genotypes } \\
\hline & $3 a$ & $1 a$ & $3 b$ & Type 4 & $\begin{array}{l}\text { Mixed } \\
\text { genotype }\end{array}$ & Total & \%age \\
\hline $10-20$ & 3 & 1 & 0 & 0 & 0 & 4 & $2.2 \%$ \\
\hline $21-30$ & 35 & 0 & 0 & 0 & 0 & 35 & 19.7 \\
\hline $31-40$ & 64 & 3 & 0 & 0 & 2 & 69 & 38.9 \\
\hline $41-50$ & 38 & 5 & 1 & 0 & 3 & 47 & 26.5 \\
\hline $51->$ & 20 & 1 & 0 & 1 & 0 & 22 & 12.4 \\
\hline Total & 160 & 10 & 1 & 1 & 5 & 177 & 100 \\
\hline
\end{tabular}


implemented in SPSS version 16 for windows (IBM Corporation, 2008). $P$ value $<0.05$ was considered significant.

Of the total 215 sera, only 177 were positive for $\mathrm{HCV}$ RNA, with almost equal representation from males and females (males $=89(50 \%)$ and females $=88(49 \%) ; P>0.05$; Figure 1). Serum samples were categorized into different age groups such as $10-20$ years, $21-30$ years, $31-40$ years, 41-50 years and above 50 years, and percentage of $\mathrm{HCV}$ RNA positive samples was determined. The prevalence of HCV positive samples was $80 \%, 75 \%, 80 \%, 87 \%$ and $95 \%$ for age groups $10-20$ years, $21-30$ years, $31-40$ years, 41-50 years, and above 50 years, respectively. There was no statistically significant difference in number of HCV RNA positive samples between different age groups $(P>0.05)$. The percentage of male HCV RNA positive samples was higher in age group 31-40 years while most of HCV RNA positive samples in age group 41-50 years were from females $(P<0.05)$ (Figure 2$)$.

Genotype 3a was found to be the most prevalent genotype $(160 / 177=90.3 \%)$, followed by genotypes $1 \mathrm{a}$ $(10 / 177=5.6 \%), 3 \mathrm{~b}(1 / 177=0.6 \%), 4(1 / 177=0.6 \%)$ and mixed genotype $(5 / 177=2.8 \%)$. Thus, genotype $3 \mathrm{a}$ was significantly more abundant than $1 \mathrm{a}, 3 \mathrm{~b}$, type 4 , and mixed genotypes $(P<0.05)$ (Figure 3$)$.

The prevalence of different $\mathrm{HCV}$ genotypes was also stratified according to age groups $10-20$ years, $21-30$ years, $31-40$ years, $41-50$ years, and above 50 years and is provided in Table 1 . While genotype 3a was predominant in all age groups, a high prevalence of genotype 1a and mixed genotypes was observed in age group 41-50 years.

Mardan is located in the southwest of province Khyber Pakhtunkhwa (KPK). Urban proportion of the district is $20.2 \%$ whereas $79.8 \%$ is the rural proportion. A report conducted by Tehsils \& Unions in the district Mardan, Government of Pakistan has mentioned that compared to urban areas HCV prevalence is more in rural areas. Therefore, out of 215 sera, 50 were taken from urban areas whereas 165 sera were taken from rural areas.

Prevalence of HCV genotypes has been reported from different areas of Pakistan. Inamullah et al. [13] reported genotype $3 \mathrm{a}(34.1 \%)$ as the most prevalent genotype in district Swat followed by genotypes $2 \mathrm{a}(8.1 \%), 3 \mathrm{~b}(7 \%)$, 1a (5.4\%) and mixed genotype (7.6\%). Ahmad et al. [14] also found $49.5 \%$ prevalence of genotype $3 a$ in district Swat. Ali et al. [15] processed $415 \mathrm{HCV}$ RNA positive patients for genotyping from Khyber Pakhtunkhwa province and found $57.83 \%$ prevalence of genotype 3a, followed by $6.2 \%$ of genotype $3 \mathrm{~b}$. In a study conducted in Lahore, Ahmad et al. [16] found 55.9\% prevalence of genotype $3 \mathrm{a}$ and $3.2 \%$ of genotype $3 \mathrm{~b}$. Overall, it has been shown that genotype $3 \mathrm{a}$ is $62 \%$ prevalent among $\mathrm{HCV}$ positive samples in Pakistan while prevalence of $3 \mathrm{~b}, 1 \mathrm{a}, 2 \mathrm{a}$ and mixed genotypes is $9 \%, 3 \%, 2.144 \%$ and $4.718 \%$, respectively [17]. In our study, we have also observed that in 41-50 years age group, females have high prevalence of $\mathrm{HCV}$ than males while this is reverse in 31-40 years age group where males are more affected than females. A total of $40 \mathrm{HCV}$ seropositive samples belonging to seven different locations of Baluchistan were studied by Afridi et al. [18] and genotype 3a was the most prevalent genotype among all samples.

When a comparative study was made among different cities and districts of Pakistan including district Mardan, genotype $3 \mathrm{a}$ was found to be the most common genotype [17]. In this study, we have also compared the prevalence of HCV among different age groups. We found that there was no specificity of HCV dissemination among different age groups and all groups showed closely related prevalence of HCV. Moreover, we observed difference of $\mathrm{HCV}$ prevalence in males and females among different age groups. The age group between $31-40$ years showed that males of this group are at high risk of having HCV infection while females of age group between $41-50$ years displayed high $\mathrm{HCV}$ infection rate than males. It will be interesting to find out the factors involved in this gender specification.

It is concluded that genotype $3 \mathrm{a}$ is the most prevalent $\mathrm{HCV}$ genotype in Mardan. The higher prevalence of HCV genotype $3 \mathrm{a}$ all around the Pakistan suggests that Pakistani population is more susceptible to genotype 3a as compared to other genotypes. Further studies on the prevalence of $\mathrm{HCV}$ genotypes in different areas of Pakistan involving large geography and population are needed which will further help to strengthen and revise preventive as well as therapeutic strategies throughout the country.

\section{Competing interests}

The authors declare that they have no competing interests.

\section{Authors' contribution}

MTY, MNZ and MZS contributed in study design and manuscript write up. $Z_{H^{3}}$ provided lab facilities and contributed reagents. SQA did perform the work whereas NM, FA and YT did analyze data and supervised the study. All authors read and approved the final manuscript.

\section{Acknowledgments}

The lab facilities and chemicals used in this study were provided by The Medical Laboratory, Lahore.

\section{Author details}

'Quality Operations Laboratory, UVAS, Lahore 54000, Pakistan. ${ }^{2}$ University Diagnostic Laboratory, University of Veterinary and Animal Sciences, Lahore 54600, Pakistan. ${ }^{3}$ Consultant Pathologist, The Medical Laboratories (Pvt), Lahore 54650, Pakistan.

Received: 17 November 2012 Accepted: 18 March 2013

Published: 20 March 2013

\section{References}

1. Alter MJ: Epidemiology of hepatitis C virus infection. World J Gastroenterol 2007, 13:2436-2441.

2. Hatzakis A, Wait S, Bruix J, Buti M, Carballo M, Cavaleri M, Colombo M, Delarocque-Astagneau E, Dusheiko G, Esmat G, Esteban R, Goldberg D, Gore C, Lok AS, Manns M, Marcellin P, Papatheodoridis G, Peterle A, Prati D, Piorkowsky 
N, Rizzetto M, Roudot-Thoraval F, Soriano V, Thomas HC, Thursz M, Valla D, van Damme P, Veldhuijzen IK, Wedemeyer H, Wiessing L, Zanetti AR, Janssen HL: The state of hepatitis B and C in Europe: report from the hepatitis B and C summit conference*. J Viral Hepat 2011, 18(Suppl. 1):1-16.

3. Kaito M, Watanabe S, Tsukiyama-Kohara K, Yamaguchi K, Kobayashi Y, Konishi M, Yokoi M, Ishida S, Suzuki S, Kohara M: Hepatitis C virus particle detected by immunoelectron microscopic study. J Gen Virol 1994, 75(Pt. 7):1755-1760.

4. Moradpour D, Wölk B, Cerny A, Heim MH, Blum HE: Hepatitis C: a concise review. Minerva Med 2001, 92:329-339.

5. Asselah T, Rubbia-Brandt L, Marcellin P, Negro F: Steatosis in chronic hepatitis C: why does it really matter? Gut 2006, 55:123-130.

6. Brohm C, Steinmann E, Friesland M, Lorenz IC, Patel A, Penin F, Bartenschlager R, Pietschmann T: Characterization of determinants important for hepatitis $\mathrm{C}$ virus $\mathrm{p7}$ function in morphogenesis by using trans-complementation. J Virol 2009, 83:1 1682-11693.

7. Jirasko V, Montserret R, Lee JY, Gouttenoire J, Moradpour D, Penin F, Bartenschlager R: Structural and functional studies of nonstructural protein 2 of the hepatitis $C$ virus reveal its key role as organizer of virionassembly. PLoS Pathog 2010, 6:e1001233.

8. Ma Y, Yates J, Liang Y, Lemon SM, Yi M: NS3 helicase domains involved in infectious intracellular hepatitis C virus particle assembly. J Virol 2008, 82:7624-7639.

9. Egger D, Wölk B, Gosert R, Bianchi L, Blum HE, Moradpour D, Bienz K: Expression of hepatitis $C$ virus proteins induces distinct membrane alterations including a candidate viral replication complex. J Virol 2002, 76:5974-5984.

10. Benga WJ, Krieger SE, Dimitrova M, Zeisel MB, Parnot M, Lupberger J, Hildt E, Luo G, McLauchlan J, Baumert TF, Schuster C: Apolipoprotein E interacts with hepatitis $C$ virus nonstructural protein $5 \mathrm{~A}$ and determines assembly of infectious particles. Hepatology 2010, 51:43-53.

11. Inamullah, Idrees M, Ahmed H, Sajid-ul-ghafoor, Ali M, Ali L, Ahmed A: Hepatitis C virus genotypes circulating in district Swat of Khyber Pakhtoonkhaw, Pakistan. Virol J 2011, 8:16.

12. Ahmad A, Ahmad B, Ali A, Ahmad Y: Seroprevalence of HBsAg and anti$\mathrm{HCV}$ in general healthy population of Swat district with frequency of different HCV genotypes. Pak J Med Sci 2009, 25:744-748.

13. Ali A, Ahmed $\mathrm{H}$, Idrees M: Molecular epidemiology of Hepatitis $\mathrm{C}$ virus genotypes in Khyber Pakhtoonkhaw of Pakistan. Virol J 2010, 7:203.

14. Ahmad W, ljaz B, Javed FT, Jahan S, Shahid I, Khan FM, Hassan S: HCV genotype distribution and possible transmission risks in Lahore, Pakistan. World I Gastroenterol 2010, 16:4321-4328

15. Butt S, Idrees M, Akbar H, ur Rehman I, Awan Z, Afzal S, Hussain A, Shahid M, Manzoor S, Rafique S: The changing epidemiology pattern and frequency distribution of hepatitis C virus in Pakistan. Infect Genet Evol 2010, 10:595-600.

16. Hussain A, Nasir Ml, Siddiqui AA, Ahmad A: Prevalence of HCV genotypes in patients reporting in tertiary health care hospital of Karachi, Pakistan. J Pharmacol 2011, 28:23-29.

17. Afridi S, Naeem M, Hussain A, Kakar N, Babar ME, Ahmad J: Prevalence of hepatitis C virus (HCV) genotypes in Balochistan. Mol Biol Rep 2009, 36:1511-1514.

18. Safi AZ, Waheed Y, Sadat J, ul Islam S, Salahuddin S, Saeed U, Ashraf M: Molecular study of HCV detection, genotypes and their routes of transmission in North West Frontier Province, Pakistan. Asian Pac J Trop Biomed 2012, 2:532-536.

\section{Submit your next manuscript to BioMed Central and take full advantage of:}

- Convenient online submission

- Thorough peer review

- No space constraints or color figure charges

- Immediate publication on acceptance

- Inclusion in PubMed, CAS, Scopus and Google Scholar

- Research which is freely available for redistribution

Submit your manuscript at www.biomedcentral.com/submit
C Biomed Central 